\title{
Comentário a \\ “Outros Inconscientes: Desconstruindo a \\ Translucidez da Consciência Sartriana”: 0 \\ ESTRANHO QUE VIVE EM MIM: LUCIDEZ E CONSCIÊNCIA \\ TRANSLÚCIDA EM SARTRE
}

Luciano Donizetti da Silva ${ }^{1}$

Referência do artigo comentado: ALT, F. Outros inconscientes: desconstruindo a translucidez da consciência sartriana. Trans/form/açáo: revista de filosofia da Unesp, v. 44, n. 4, p. 193-212, 2021.

Uma das coisas mais atraentes na vasta obra sartriana é saber que $o$ homem é livre; alegria do neófito em filosofia quando, depois de submeterse à sisudez de Aristóteles a Kant, ou desgastantes malabarismos medievais e modernos sobre Alma ou Sujeito, ele encontra Sartre: ser homem é ser liberdade. Não há Deus, nem Natureza ou Lei, Dialética ou Mão Invisivel... há liberdade, e dela toda ética; são os homens e mulheres que escolhem seu ser, e aquilo que são no mundo faz com que o mundo seja como é. Sob efeito da idealização da liberdade, futuros filósofos descobrem que ser livre exige responsabilidade em igual medida. Fiando-se em Husserl e sua intencionalidade, Sartre fez da consciência movimento de si a si; todavia, descrente de toda Epoché, ele situa essa consciência-fluxo no mundo, em situaçẫo (noção emprestada de Heidegger).

\footnotetext{
${ }^{1}$ Professor de Filosofia Contemporânea no Departamento de Filosofia e na Pós-Graduação em Filosofia no Instituto de Ciências Humanas da Universidade Federal de Juiz de Fora (ICH-UFJF), Juiz de Fora, MG - Brasil. D https://orcid.org/0000-0003-0584-7377. E-mail: donizetti.silva@hotmail.com.
}

https://doi.org/10.1590/0101-3173.2021.v44n4.17.p225

\section{(i)}


Foi a partir de indagaçóes fenomenológicas que Sartre erigiu sua ontologia: homem-no-mundo revela-se Ser-para-si, essa espantosa interioridade virada às avessas. Ser homem é manter-se movimento de si a si passando pelo mundo; ou, porque é livre, ele encarna a liberdade (escolhe), mas ele é também suas escolhas pregressas reificadas pelo olhar do outro - livre, ele escolheu e deverá ainda escolher. O Ego habita o mundo, e queiramos ou não, somos aquilo que o olhar de outrem revela: sou meu passado ao modo de não mais o ser, visto que a consciência é movimento que se unifica por seu fluxo.

Essa característica única de ser-para-si, a qual é seu passado como tendo-o sido e é seu futuro náo o sendo ainda (projeto), espanta muitos daqueles que, de início, se interessaram pela filosofia da liberdade. De fato, tem-se um duplo desafio: o que somos advém do mundo, já repleto de sentidos próprios elaborados por outros homens que nos antecederam, o que parece anular a liberdade (passado) e, ao mesmo tempo, é exigido escolher-nos e escolher o mundo, perpétua e livremente (futuro). Ora, a consciência é sim translucidez, que, para Sartre, somente pode se realizar, caso ela seja afetada de opacidade (presença ao mundo, outro); e, nesse campo, é preciso lidar com o passado, o corpo, a facticidade, a subjetividade... enfim, a travessia da sala escura ou a infância, porta única pela qual todo homem ou mulher pode adentrar o mundo; e o mundo (e isso não é retórica) também é (e somente poderia ser) humano.

É nesse ambiente que aparece o intrincado problema da translucidez da consciência, desenvolvido em Outros inconscientes: desconstruindo a translucidez da consciência sartriana. E não apenas hoje, mas desde muito, é lícito perguntar, como faz (ALT, 2021, p. 194): afinal, “[...] o ser humano se conhece ou não? Domina ou não suas próprias ações? Há desejos que, de profundos, estariam além das escolhas voluntárias?”

Sartre era homem de seu tempo, mas hoje, como antes, não parece lícito, ou lúcido, negar aquilo que a verdade fenomênica revela: algo em nós remete ao que poderia ser chamado inconsciente, subconsciente ou pré-consciente; todo homem foi criança, donde, para além da existência clara e distinta, há muita obscuridade em ser-para-si - mesmo que a consciência seja translúcida. Notam-se duas apreensôes de homem: aquele aqui agora, encarnado, e $o$ homem, essa entidade que paira desde sempre sobre todas as existências; no primeiro caso, que parece o adequado à fenomenologia, estar aqui exige ter sido criança. A dicotomia homem e eu-homem repete, em instâncias distintas, a mesma dificuldade da escolha original: sou meu passado, à maneira de não mais 
sê-lo, e somente posso ser agora, porque fui esse passado que ainda sou; a isso é preciso adicionar o agravante de que a consciência não pode ser acrescida ao homem: ou ele é consciência ou jamais será (consciência não é adendo, conf. crítica de Sartre a Heidegger).

Assim a criança é, e somente poderia ser, consciência? Sim, ao que parece, o que inaugura o ambiente da escolha de ser (escolha consciente, porém, não sabida), o lugar próprio da pré-reflexão. Aquilo que a criança foi, e que permanece no adulto, é ainda consciência e leva consigo tudo que esse para-si era, mesmo que ele não saiba; ou melhor, ele pode sim vir a saber, mas terá em seu apoio somente aquilo que outros (adultos) puderem relatar, somado a poucas memórias e, a depender da idade, nada. A investigação sobre Flaubert, em sua parcela regressiva, vai até o momento mais originário possível, até a genitrix do poeta, e o que se encontra até ali é ainda Gustave; fiel à fenomenologia, Sartre admite o não sabido de todos nós. E lúcido, compreende que não há nada fora da consciência.

Assim, Sartre aposta no ser-consciente ainda que não-sabido? A sala é escura, mas é preciso atravessá-la para ser homem, não custa lembrar. E a ontologia volta à baila: sem recorrer a purificaçóes ou reduçóes, obsessão de filosofias idealistas, Sartre nomeia acontecimento absoluto esse aparecimento do nada no seio do ser, que traz o ser ao mundo pela presença negativa do para-si (Ek-sistere); em termos ônticos, é demandada reflexão (saber), para que a criança seja aceita no mundo adulto (como se a idade da razão fosse debute). Contudo, não importando o quilate intelectual, Freud ou Flaubert, evidenciase necessariamente seu ter-sido-criança; e erro e ilusão espreitam a pureza do apriorismo. Melhor revisitar aquele ser-ausência do sujeito transcendental, aprisionado num mundo de verdades que exige negar a infância?

No entanto, se assim for, como lidar com o fato de que homens não nascem com cartola nem com carteira de trabalho? A consciência intencional, translúcida, parece carecer de lucidez, não quando se engana ou não sabe, mas quando se pretende independente daquela carcaça (corpo-vivido), unicamente de onde ela pode voltar-se para si mesma. Entáo, translucidez aqui náo exige identidade, porque o ser-homem (refletir) se faz desde esse outro que ele foi e daquele outro que ele será; acrescente-se a isso a contingência do Ser e temse, além do não-saber de si, a ilusão de alguma sorte de domínio de si. $\mathrm{Ou}$ seja, a translucidez da consciência não demanda negar o acontecimento absoluto: a quimera da subjetividade pura se esvai, bastando para isso lembrar o tautológico de nossa finitude (nós nascemos!); ser-consciência de ponta a 
ponta não significa saber-se na mesma medida, o que bem mostra a psicanálise existencial.

Para Sartre, ser consciência intencional é algo bem diferente daquelas noçóes de pura subjetividade, as quais dariam razão a reprimendas à filosofia da liberdade como náo encarnada ou de sobrevoo (conforme discute o artigo). E que isso possa ser identificado num momento específico da obra de Sartre (ele passou a admitir explicitamente que a consciência envolve opacidade) reforça ainda mais a posição mundana (situada, efetiva, ainda que implícita), na qual a consciência é sim intencional e, portanto, aquele sopro... explosáo em direção $a$, que nasce (brota, revela-se) de um corpo no mundo, de olhos e mãos e sentimentos e tudo mais que cada homem e mulher revela sendo; homem livre, sim, mas que se recusa a permanecer de má-fé, quando passa da reflexão impura à reflexão pura. E reconhece, antes de toda reflexão, que foi criança consciente, que foi incapaz de memorizar, analisar e julgar tudo o que, de certo modo, ainda $e ́$; homem livre que não renega seu passado, visto agora saber que não seria sem ele. É assim que a subjetividade pode ser pensada como escape (características de um espectro): ela escapa de si mesma ou do mundo...

Outra vez o outro, aquele mesmo que me destrona de meu reinado, é o único capaz de me trazer ao mundo: sou homem através de outros homens, e somente um ato de má-fé poderia negar esse fato fenomenológico. A consciência permanece consciência translúcida, sendo que a lucidez exige admitir que também somos carne de ponta a ponta: ser-no-mundo é ser habitado por um estranho que, no fundo, somos nós mesmos, sem o saber.

\section{REFERÊNCIAS}

ALT, F. Outros inconscientes: desconstruindo a translucidez da consciência sartriana. Trans/form/açáo: revista de filosofia da Unesp, v. 44, n. 4, p. 193-212, 2021.

Recebido: $12 / 3 / 2021$

Aceito: $15 / 3 / 2021$ 